\title{
Powdery mildew (Erysiphaceae) on Calibrachoa hybrids in Germany, Nicaragua and the USA
}

\author{
Brielmaier-Liebetanz $\mathbf{U}^{1}$, Field $A E^{2}$, Warfield $C Y^{2}$ and Braun $\mathbf{U}^{3^{*}}$ \\ ${ }^{1}$ Julius Kühn-Institut (JKI), Institut für Pflanzenschutz in Gartenbau und Forst, Messeweg 11/12, 38104 Braunschweig, \\ Germany \\ ${ }^{2}$ Ball Horticultural Company, 622 Town Rd, West Chicago, IL 60185, USA \\ ${ }^{3}$ Martin-Luther-Universität, Institut für Biologie, Bereich Geobotanik und Botanischer Garten, Herbarium, Neuwerk \\ 21, 06099 Halle/S., Germany
}

Brielmaier-Liebetanz U, Field AE, Warfield CY, Braun U 2015 - Powdery Mildew (Erysiphaceae) on Calibrachoa hybrids in Germany and the USA. Plant Pathology \& Quarantine 5 (1), 1-5, Doi $10.5943 / \mathrm{ppq} / 5 / 1 / 1$

\begin{abstract}
Cultivated Calibrachoa hybrids were previously thought to be resistant to powdery mildew, but infections have been recently encountered in Germany, USA and Nicaragua. The exclusive development of asexual morphs (anamorphs) led to the question as to which powdery mildew species might be involved as causal agents. Based on inoculation experiments and molecular sequence analyses, it was determined that powdery mildew infections on Calibrachoa in Europe (Germany), North America (USA), and Central America (Nicaragua) were found to be caused by the plurivorous Podosphaera xanthii. The anamorph is a typical Fibroidium characterized by conidia formed in chains (catenescent), containing distinct fibrosin bodies. Calibrachoa powdery mildew caused by $P$. xanthii could be easily transferred to cucumber, squash and Verbena $\times$ hybrida and vice versa in the latter case. Attempts to inoculate petunias failed. In addition to P. xanthii, two additional powdery mildew species were found infecting Calibrachoa xhybrida in Germany. The first, characterized by having lobed hyphal appressoria and conidia formed singly, can be assigned to Pseudoidium neolycopersici, and the second species, readily distinguishable by its very long conidiophores, conidia in chains with sinuate outline and nipple-shaped hyphal appressoria, belongs to Euoidium longipes. In the course of the current examinations, E. longipes was also found on Verbena $\times$ hybrida, which represents the first record of this species on a non-solanaceous host.
\end{abstract}

Key words - Erysiphales - Euoidium longipes - Podosphaera xanthii - Pseudoidium neolycopersici - Solanaceae - Petunia

\section{Introduction}

Since its introduction in the mid-1990s as an ornamental plant, Calibrachoa has become the second largest vegetative bedding plant in North America and Europe based on the number of cuttings produced and sold (M. Miller, personal communication). Calibrachoa 'Double Ruby' was 
selected as "Balcony Plant of the Year 2012" in Rheinland-Pfalz, Germany (www.gartenbaurlp.de/index.php/component/item/103-rheinland-pfälzische-balkonpflanze-des-jahres-2012).

Powdery mildew infections on Calibrachoa were only recently observed in Germany (on non-commercial genotypes) where it was previously thought that Calibrachoa was resistant to powdery mildew. However, observations and examinations of naturally infected Calibrachoa hybrids had been made in the USA (Warfield 2011). European as well as North American Calibrachoa powdery mildew only occurs as an asexual morph (anamorph), fruiting bodies (chasmothecia) are not formed. Three different powdery mildew species have been encountered in the course of the present examinations. Based on indistinct to nipple-shaped hyphal appressoria, conidia formed in chains and conspicuous fibrosin bodies, one of the mildews can easily be classified as Fibroidium (R.T.A. Cook et al.) R.T.A. Cook \& U. Braun, the anamorph of Podosphaera Kunze (Braun \& Cook 2012). However, plants of various genera belonging to the Solanaceae may be hosts of two different species of the latter genus, namely the recently described Podosphaera solanacearum U. Braun and P. xanthii (Castagne) U. Braun \& Shishkoff (Braun \& Cook 2012). The two species are discriminated by traits of the ascomata, but their asexual morphs are indistinguishable. This led to the question which species might be involved as the causal agent of this Calibrachoa powdery mildew disease. Inoculation experiments and molecular sequence analysis were carried out to answer this question. Two additional anamorphic powdery mildews observed on Calibrachoa hybrids proved to be morphologically quite distinct from the Podosphaera anamorph and pertain to Euoidium Y.S. Paul \& J.N. Kapoor (Golovinomyces (U. Braun) Heluta anamorph) and Pseudoidium Y.S. Paul (Erysiphe DC. anamorph).

\section{Materials \& Methods}

The fungal material was examined by standard light microscopy using oil immersion (bright field and phase contrast), but without any staining. Thirty measurements ( $\times 1000$ magnification) of conidia and other structures were made, with the extremes given in parentheses.

To confirm the identification of the North American isolate, total genomic DNA was extracted from Calibrachoa leaves visibly infected with powdery mildew. Leaves were collected in April 2011 from infected plants growing in a trial greenhouse in coastal California. DNA isolation was based on a modified protocol described by Dellaporta et al. (1983). The complete internal transcribed spacer (ITS) region of rDNA, including 5.8S rDNA, the $3^{\prime}$ end of 18S rDNA and the 5' end of 28S rDNA, was amplified and sequenced with primer pair ITS1-ITS4 using procedures outlined in White et al. (1990). PCR reactions were carried out using GoTaq Flexi DNA polymerase (Promega, Madison, Wisconsin) in a thermal cycler (2720 Geneamp, Life Technologies Corporation). The PCR DNA products were cleaned using a commercial kit following the manufacturer's protocol (QIAquick PCR Purification kit, Qiagen Valencia, CA). Visualization of the PCR products was obtained by electrophoresis in $1.8 \%$ agarose gels in TBE buffer. Direct sequencing of the PCR products was performed by the DNA Facility of the Iowa State University Office of Biotechnology (Ames, Iowa). Sequencher software (Gene Codes Corporation, Ann Arbor, MI) was utilized to obtain a consensus sequences for the amplified region. The resulting 536 bp sequence was deposited in GenBank, as Podosphaera xanthii (Accession no. KP256814). The obtained sequence was used in the BLASTN 2.2.25+ program (NCBI http://www.ncbi.nlm.nih.gov/) to determine taxon identity based on similarity between sequences expressed as percent sequence identity.

Inoculation experiments were conducted on Cucumis sativus, Verbena $\times$ hybrida and Calibrachoa $\times$ hybrida. Two young cucumber plants 'Delikatess', as well as four detached leaves in double petri plates, were inoculated by brush application with the Podosphaera anamorph (Fibroidium) originating from Calibrachoa hybrids. Four young plants of Verbena $\times$ hybrida 'Obsession White' were treated in the same way. Conversely, 12 in vitro plantlets of a Calibrachoa genotype with known susceptibility to powdery mildew were inoculated with conidia originating from Verbena $\times$ hybrida. Inoculated plant material was incubated in a growth chamber at $20^{\circ} \mathrm{C}$ and 
12 hours light. Non inoculated plants kept separately under the same conditions were used as controls.

Transfer experiments with powdery mildew from Calibrachoa to Petunia were performed under greenhouse conditions. Two Calibrachoa hybrid plants predominantly infected with a Podosphaera anamorph were placed between four plants of Petunia hybrids known to be susceptible to powdery mildew.

The identity of the developing powdery mildew was microscopically checked. Voucher herbarium specimens are deposited in the Herbarium of the Martin Luther University, Halle (Saale), Germany.

\section{Results}

Three different powdery mildews have been observed on Calibrachoa xhybrida. One of them, detected in Germany, Nicaragua, and the USA, is morphologically characterized by the formation of thin white patches on leaves, composed of branched superficial hyphae, 3-8 $\mu \mathrm{m}$ wide, septate, thin-walled, smooth, with indistinct to somewhat nipple-shaped hyphal appressoria. The conidiophores are straight, erect, composed of cylindrical foot-cells, 30-70 $\times 9-12 \mu \mathrm{m}$, followed by 1-2 shorter cells, giving rise to catenescent conidia, ellipsoid-doliiform, 25-35 $\times 15-21 \mu \mathrm{m}$, with conspicuous fibrosin bodies (herbarium material deposited as HAL 2611 F: on Calibrachoa hybrid, Germany, Niedersachsen, Braunschweig, 9 Oct. 2013, U. Brielmaier-Liebetanz). Based on these morphological characteristics, this powdery mildew can readily be classified as Fibroidium, the anamorph of Podosphaera. However, the identification of a particular species based only on the anamorph was not possible.

Mixed infections of two additional, morphologically distinct powdery mildews have also been found on Calibrachoa in Germany. The most abundant of these differs from P. xanthii by the formation of lobed hyphal appressoria and conidia formed singly (hyphae 3-8 $\mu \mathrm{m}$ wide; hyphal appressoria solitary or mostly in opposite pairs, slightly lobed to multi-lobed, 2-9 $\mu \mathrm{m}$ diam.; conidiophores arising from upper surface or slightly lateral from the mother cell of superficial hyphae, more or less centrally or mostly towards one end of the cell, erect, straight, up to about 100 $\mu \mathrm{m}$ long, foot-cells cylindrical $20-45 \times 8-10 \mu \mathrm{m}$, followed by $1-2$ cells, shorter than the foot-cell, about as long or even longer; conidia formed singly, ellipsoid-doliiform, 28-50 × 13-20 $\mu \mathrm{m}$, position of germ tubes perihilar, short to moderately long, apex with lobed to multi-lobed appressorium). These characteristics closely match those of Pseudoidium neolycopersici (L. Kiss) L. Kiss (in Braun \& Cook 2012), except for more variability in the length of the cells following the conidiophore foot-cells. Material has been deposited as P. neolycopersici at HAL (on Calibrachoa $\times$ hybrida, Germany, Niedersachsen, Braunschweig, 9 Oct. 2013, U. Brielmaier-Liebetanz, HAL 2612 F). On leaves infected with $P$. neolycopersici, visible colonies of Euoidium longipes (Noordel. \& Loer.) U. Braun \& R.T.A. Cook were also present. E. longipes, was easily discernible by its very long conidiophores mostly composed of a relatively short foot-cell followed by a very long cell, about 60-300 $\mu \mathrm{m}$ long, and 0-4 short cells, conidia in chains with sinuate outline, without fibrosin bodies and nipple-shaped hyphal appressoria. The occurrence of E. longipes on Verbena $\times$ hybrida under greenhouse conditions was an additional, interesting observation during the course of the present examinations (material deposited as HAL $2665 \mathrm{~F}$ and HAL $2666 \mathrm{~F}$ ).

Comprehensive descriptions and illustrations of the powdery mildew species concerned have recently been published by Braun \& Cook (2012), which can be used as reference and source for comparison.

\section{Inoculation experiments}

Inoculation and host range experiments with powdery mildew inoculum from naturally infected Calibrachoa hybrids in Germany and the USA showed interesting results. It was possible to transfer this powdery mildew to cucumber (Germany), squash (USA) and Verbena $\times$ hybrida, all principal hosts of Podosphaera xanthii, and vice versa. A Fibroidium anamorph from Verbena 
xhybrida was successfully transferred to Calibrachoa hybrids in Germany. On the other hand, attempts to transfer the Calibrachoa Fibroidium onto petunias failed in all German and North American experiments.

\section{Phylogenetic analysis}

A GenBank BLAST search of the complete ITS sequence obtained from the North American Calibrachoa isolate showed 100\% similarity with the ITS sequence of numerous Podosphaera isolates including Podosphaera xanthii (AB046985.1, on Verbena $\times$ hybrida, USA), P. xanthii (AB040339.1, on Saintpaulia sp., Australia), P. phaseoli (Z.Y. Zhao) U. Braun \& S. Takam. (GQ927253.1, on Vigna unguiculata, China), P. balsaminae (Wallr.) U. Braun \& S. Takam. (FJ625796.1, on Impatiens balsamina, China), and P. fusca (Fr.) U. Braun \& Shishkoff (KJ698669.1, on Cucurbita pepo, Italy). All of these powdery mildews belong to P. xanthii. P. phaseoli has been reduced to synonyms with P. xanthii, and Podosphaera on Impatiens balsamina refers to P. xanthii as well (Braun \& Cook 2012). True P. balsaminae is confined to Impatiens nolitangere in Asia and Europe and is morphologically and genetically distinct. The use of the name $P$. balsaminae for powdery mildew collections on Impatiens balsamina is a case of misapplication. $P$. fusca (s. str.) is now confined to powdery mildew on Doronicum spp. (Braun \& Cook 2012). The nucleotide sequence of the $P$. xanthii collected in December 2014 from calibrachoa plants under cultivation in Nicaragua had $100 \%$ identity with the rDNA ITS sequence of the North American (California) isolate.

\section{Key to powdery mildews occurring on Calibrachoa $\times$ hybrida}

The following key is intended to facilitate the identification of asexual morphs of powdery mildews on Calibrachoa $\times$ hybrida, and includes confirmed and potential species (marked by an asterisk).

1. Hyphal appressoria lobed, mostly in opposite pairs; foot-cells of the conidiophores relatively short, about 20-60 × 6-10 $\mu \mathrm{m}$; conidia formed singly ...................... Pseudoidium neolycopersici

1. Hyphal appressoria indistinct to nipple-shaped, mostly solitary; foot-cells of the conidiophores often longer $(>60 \mu \mathrm{m})$ and wider above, about 10-14 $\mu \mathrm{m}$; conidia catenescent (formed in true chains).....

2. Edge line of chained immature conidia crenate; fresh conidia with distinct fibrosin bodies Podosphaera xanthii

2. Edge line of chained immature conidia sinuate; conidia without fibrosin bodies..... 3

3. Width of the conidiophores distinctly increasing from base to top, foot-cells $40-90 \mu \mathrm{m}$ long, followed by 1-2 often longer cells, about 50-300 $\mu \mathrm{m}$ long Euoidium longipes

3. Width of the conidiophores not distinctly increasing, foot-cells followed by 1-2 much shorter cells

4. Foot-cells 95-180 $\mu \mathrm{m}$ long; on Solanaceae, Australia. *Euoidium lycopersici

4. Foot-cells shorter, 30-100 $\mu \mathrm{m}$; on hosts of various genera of the Solanaceae (found worldwide in greenhouses) *Golovinomyces orontii

\section{Discussion}

In conclusion, the powdery mildew detected on Calibrachoa xhybrida in Europe as well as North and Central America, characterized by catenescent conidia with fibrosin bodies, was confirmed as the plurivorous Podosphaera xanthii based on morphology, pathogenicity assays and molecular analysis of the complete internal transcribed spacer sequence. P. xanthii on cucurbits, Verbena $\times$ hybrida and other hosts of this species should be considered as potential sources of infection on Calibrachoa $\times$ hybrida. These results suggest a potential threat to calibrachoa by $P$. xanthii wherever this ornamental plant is cultivated. 
In the USA as well as in Germany, transfers of the calibrachoa powdery mildew onto several varieties of petunias, using both brush transfers and wet inoculations, failed to infect any of the petunia varieties inoculated, which conflicts with Catlin (2012) who listed Podosphaera xanthii as a causal agent of petunia powdery mildew, but without any further information or references.

It appears that Pseudoidium neolycopersici, the common tomato powdery mildew, is able to infect calibrachoa, at least under greenhouse conditions. This is the first record of this powdery mildew on Calibrachoa $\times$ hybrida. Euoidium longipes on calibrachoa is also new and hitherto not yet reported.The observation of E. longipes on Verbena $\times$ hybrida represents the first record of this species on a non-solanaceous host.

Euoidium lycopersici (Cooke \& Massee) U. Braun \& R.T.A. Cook and Golovinomyces orontii (Castagne) Heluta, two additional species on hosts of the Solanaceae, are potential powdery mildew threats for calibrachoa, although not yet observed on calibrachoa.

\section{References}

Braun U, Cook RTA. 2012 - Taxonomic Manual of the Erysiphales (Powdery Mildews). CBS Biodiversity Series 11, 1-707.

Catlin N. 2012 - Powdery mildew on Petunia. E-Gro Alert 1(12), 1-2.

Dellaporta SL, Wood J, Hicks JB.1983 - A plant DNA minipreparation: Version II. Plant Molecular Biology Reporter 1, 19-21.

Warfield CY. 2011 - Squashing Powdery Mildew in Calibrachoa. Growertalks 75(4), 76-78.

White TJ, Bruns T, Lee S, Taylor J. 1990 - Amplification and direct sequencing of fungal ribosomal RNA genes for phylogenetics. Pp. 315-322, In: Innis MA, Gelfand DH, Sninsky JJ, White TJ. (eds.) PCR Protocols: A Guide to Methods and Applications. Academic Press, San Diego. 